\title{
SOIL CHEMICAL PROPERTIES AND GROWTH OF SUNFLOWER (Helianthus annuus L.) AS AFFECTED BY THE APPLICATION OF ORGANIC FERTILIZERS AND INOCULATION WITH ARBUSCULAR MYCORRHIZAL FUNGI
}

\author{
Apolino José Nogueira da Silva(1)*, Ricardo Alencar da Silva(1), Juliana da Silva Santos(1), \\ Jordan Carlos Silva de Medeiros(1), Fabíola Gomes de Carvalho(2), Valéria Nogueira \\ da Silva(3), Cosme Jales de Oliveira(1), Afrânio César de Araújo(1), Luiz Eduardo Souza \\ Fernandes da Silva(1) and Júlio Gomes Junior(1)
}

(1) Universidade Federal do Rio Grande do Norte, Unidade Acadêmica Escola Agrícola de Jundiaí, Macaíba, Rio Grande do Norte, Brasil

(2) Instituto Federal de Educação, Ciência e Tecnologia do Rio Grande do Norte, Departamento de Recursos Naturais, Natal, Rio Grande do Norte, Brasil.

(3) Universidade Federal do Rio Grande do Norte, Departamento de Engenharia Química, Natal, Rio Grande do Norte, Brasil.

* Corresponding author.

E-mail: ajndas@ufrnet.br

\begin{abstract}
The use of organic fertilizers and the inoculation of mycorrhizal fungi in the cultivation of oil crops is essential to reduce production costs and minimize negative impacts on natural resources. A field experiment was conducted in an Argissolo Amarelo (Ultisol) with the aim of evaluating the effects of fertilizer application and inoculation of arbuscular mycorrhizal fungi on the growth attributes of sunflower (Helianthus annuus L.) and on soil chemical properties. The experiment was conducted at the Federal University of Rio Grande do Norte, Brazil, using a randomized block design with three replicates in a $4 \times 2$ factorial arrangement consisting of four treatments in regard to application of organic fertilizer (liquid biofertilizer, cow urine, mineral fertilizer, and unfertilized control) and two treatments in regard to arbuscular mycorrhizal fungi (with and without mycorrhizal fungi). The results showed that the physiological attributes of relative growth rate and leaf weight ratio were positively influenced by fertilization, compared to the control treatment, likely brought about by the
\end{abstract}


supply of nutrients from the fertilizers applied. The growth and productivity attributes were positively affected by mycorrhization.

Keywords: nutrient uptake, Ultisol, organic fertilizers, growth attributes.

\title{
RESUMO: PROPRIEDADES QUÍMICAS DO SOLO E CRESCIMENTO DE GIRASSOL (Helianthus annuus L.) EM RAZÃO DA APLICAÇÃO DE FERTILIZANTES ORGÂNICOS E INOCULAÇÃO COM FUNGOS MICORRÍZICOS ARBUSCULARES
}

\begin{abstract}
O uso de fertilizantes orgânicos e a inoculação de fungos micorrízicos no cultivo de oleaginosas é essencial para reduzir os custos de produção e minimizar os impactos negativos sobre os recursos naturais. Um experimento em campo foi realizado em um Argissolo Amarelo com o objetivo de avaliar os efeitos da aplicação de fertilizantes orgânicos e a inoculação de fungo micorrízico arbuscular nas variáveis de crescimento de girassol (Helianthus annuus L.) e nas propriedades químicas do solo. O experimento foi realizado na Universidade Federal do Rio Grande do Norte, utilizando um delineamento em blocos casualizados com três repetições, em esquema fatorial $4 \times 2$, com quatro tratamentos envolvendo a aplicação de adubos (biofertilizante líquido, urina de vaca, adubação mineral e testemunha) e dois tratamentos com fungos micorrízicos arbusculares (com e sem fungo micorrizico). Os resultados evidenciaram que as variáveis fisiológicas taxa de crescimento relativo e razão de massa foliar foram influenciadas positivamente pela adubação, em relação à testemunha, provavelmente motivada pelo fornecimento de nutrientes dos fertilizantes aplicados. As variáveis de crescimento e de produtividade foram positivamente influenciadas pela micorrização.
\end{abstract}

Palavras-chave: absorção de nutrientes, Argissolo Amarelo, fertilizantes orgânicos, variáveis de crescimento.

\section{INTRODUCTION}

Sunflower (Helianthus annuus L.) is the fourth oil crop in grain production and the fifth in cultivated area in the world. The crop has important agronomic characteristics, such as resistance to drought and cold, with wide adaptability to different soil and climatic conditions (Miragaya, 2005). Approximately $70 \%$ of the Northeast region of Brazil has soil and climatic conditions suitable for the cultivation of plants for biodiesel production. In this region, cultivation of oil plants for energy production is important for societal inclusion, generating job opportunities (Beltrão, 2005).

Chemical fertilizers are among the most expensive materials used in agriculture, and, despite their importance for crop production, they are usually inaccessible to poor farmers because of high manufacturing costs from the use of imported inputs. Another important aspect is the fact that $\mathrm{N}$, P, and $\mathrm{K}$ chemical fertilizers produce waste that contaminates soil and water resources during the manufacturing process, and can also acidify and/or salinize soils when used in agriculture, resulting in increased costs for soil amendment (Moura Filho e Alencar, 2008).

The use of organic fertilizers can reduce the application of chemical fertilizers in agriculture.
Such organic fertilizers can be drawn from residues generated on the farm, such as crop residues, livestock and poultry manure, cow urine, earthworm humus, and various biofertilizers (Moura Filho e Alencar, 2008). The use of these inputs, however, is often restricted, due to factors such as lack of studies proving response of the plant to organic fertilization, the need to apply large quantities per hectare, and slow release of nutrients when compared to soluble chemical fertilizers (Figueiredo et al., 2008).

The biotechnology of inoculation of plant roots with arbuscular micorrhizal fungi (AMF) is also an option for reducing the role of soluble chemical fertilizers used in conventional farming (Cardoso et al., 1992). The use of mycorrhization in crops of economic value, such as crops for biodiesel production, is very important in family farming. As well as reducing production costs due to greater uptake of nutrients like $\mathrm{P}, \mathrm{Zn}$, and $\mathrm{Cu}$, this biotechnology helps to decrease contamination of soil and water resources since fewer chemical fertilizers are used (Modesto et al., 2009; Braghirolli et al., 2012).

The aim of this study was to evaluate the effects of application of organic fertilizers and inoculation with arbuscular mycorrhizal fungi on the growth attributes of sunflower (Helianthus annuus L.) and on soil chemical properties. 


\section{MATERIAL AND METHODS}

\section{Experimental area}

A field experiment was conducted in an Argissolo Amarelo distrófico (Embrapa, 2006), or Ultisol in the FAO soil classification, at coordinates $5^{\circ}$ $52^{\prime} \mathrm{S}$ and $35^{\circ} 21^{\prime} \mathrm{W}$ and average altitude of 16 $\mathrm{m}$ located at the Universidade Federal do Rio Grande do Norte, in the municipality of Macaiba, Rio Grande do Norte, Brazil. The local climate is a transition between As' and BSh' of the Köppen classification, with rains in autumn and winter, mean temperature of $26^{\circ} \mathrm{C}$, and mean rainfall of $1,548 \mathrm{~mm}$. Accumulated rainfall was $547 \mathrm{~mm}$ during the months of the experiment. The chemical and physical characteristics of the soil under study are $\mathrm{pH}\left(\mathrm{H}_{2} \mathrm{O}, 1: 2.5\right) 6.1$; electrical conductivity (EC) $0.05 \mathrm{dS} \mathrm{m}^{-1} ; 22.0 \mathrm{mg} \mathrm{dm}^{-3} \mathrm{P}$ (Mehlich-1); $5.07 \mathrm{~g} \mathrm{~kg}^{-1}$ total organic carbon; $0.0 \mathrm{cmol}_{\mathrm{c}} \mathrm{kg}^{-1} \mathrm{Al}^{3+}$; $1.82 \mathrm{cmol}_{\mathrm{c}} \mathrm{kg}-1 \mathrm{H}^{+} ; 0.19 \mathrm{cmol}_{\mathrm{c}} \mathrm{kg}^{-1} \mathrm{~K}^{+}$; $0.88 \mathrm{cmol}_{\mathrm{c}} \mathrm{kg}^{-1} \mathrm{Ca}^{2+} ; 0.33 \mathrm{cmol}_{\mathrm{c}} \mathrm{kg}^{-1} \mathrm{Mg}^{2+}$; $0.03 \mathrm{cmol}_{\mathrm{c}} \mathrm{kg}^{-1} \mathrm{Na}^{+} ; 0.21 \mathrm{mg} \mathrm{dm}^{-3} \mathrm{~B} ; 12.0 \mathrm{mg} \mathrm{dm}^{-3} \mathrm{Fe}$; $2.74 \mathrm{mg} \mathrm{dm}^{-3} \mathrm{Mn} ; 0.21 \mathrm{mg} \mathrm{dm}^{-3} \mathrm{Cu} ; 2.14 \mathrm{mg} \mathrm{dm}^{-3} \mathrm{Zn}$; bulk density of $1.52 \mathrm{~kg} \mathrm{dm}^{-3}$, and sand, silt, and clay contents of 930,50 , and $20 \mathrm{~g} \mathrm{~kg}^{-1}$, respectively.

In this experiment, sunflower (Helianthus annuus L.) was used as a test plant. Row spacing was $0.80 \mathrm{~m}$, and the distance between plants in the row was $0.4 \mathrm{~m}$, resulting in a sowing density of 31,250 plants ha-1. Sunflower seeds were sown in plastic bags with a substrate composed of soil and bovine manure in a $2: 1$ ratio by volume. Seedlings were transplanted in the field 30 days after sowing.

The effects of sources of organic fertilizers and inoculation with arbuscular mycorrhizal fungi on the development of sunflower were studied through an experiment conducted in a randomized block design with three replicates in a $4 \times 2$ factorial arrangement consisting of four treatments in respect to fertilizer [liquid biofertilizer (LB), cow urine (CU), mineral fertilizer (MF), and unfertilized treatment - control $(\mathrm{C})$ ] and two treatments in respect to arbuscular mycorrhizal fungi (with and without inoculation of mycorrhizal fungi). The experiment consisted of a total of $246.4-\mathrm{m}^{2}$ plots, with six plants in the two central rows composing the useful area.

The arbuscular mycorrhizal fungi (AMF) used was Glomus fasciculatum Gerd. \& Trappe, with the inoculum consisting of clay, containing an average of 20 spores $\mathrm{g}^{-1}$ of soil. The mycorrhizal inoculum was produced in roots of Brachiaria decumbens cultivated in clay soil. G. fasciculatum was inoculated on sunflower by adding $5.0 \mathrm{~g} / \mathrm{plant}$ of inoculum, applied directly into the soil below each seed.

Soil liming was determined according to IPA (2008), based on soil chemical analysis. The amount of dolomitic lime applied was $1.6 \mathrm{Mg}^{\mathrm{ha}} \mathrm{a}^{-1}$, uniformly incorporated in the experimental area at a depth of $20 \mathrm{~cm}$ by disking, three months before planting. In field experiments, basic fertilization was performed according to the treatments under study. In treatment with mineral fertilization, basic fertilization was carried out according to Ribeiro et al. (1999), with application of 20,30, and $15 \mathrm{~kg} \mathrm{ha}^{-1}$ of $\mathrm{N}, \mathrm{P}_{2} \mathrm{O}_{5}$, and $\mathrm{K}_{2} \mathrm{O}$, respectively, based on soil chemical analysis (Ribeiro et al., 1999), using the fertilizers urea, superphosphate, and potassium chloride, in granular form.

In treatments with liquid biofertilizer and cow urine, $11.5 \mathrm{Mg} \mathrm{ha}^{-1}$ of bovine manure, calculated according to Penteado (2003), was applied as basic fertilization.

In topdressing mineral fertilization, $40 \mathrm{~kg} \mathrm{ha}^{-1}$ of $\mathrm{N}$ as urea and $15 \mathrm{~kg}$ ha-1 of $\mathrm{K}_{2} \mathrm{O}$ as potassium chloride were applied in granular form 60 days after seeding.

In topdressing with liquid biofertilizer, $10 \mathrm{~mL}$ per plant at a concentration of $4 \%$ was carried out weekly up to 45 days after seedling transplant. The liquid biofertilizer was prepared through an anaerobic system in a plastic container with fresh bovine manure and stored for a maximum period of 30 days, as described by Silva et al. (2007).

During treatment with cow urine, topdressing fertilization was performed weekly up to 45 days after transplant using $10 \mathrm{~mL}$ per plant at a concentration of $2 \%$. The cow urine was collected from cows in the lactation stage, and was stored in a plastic container, disinfected, and sealed. The liquid biofertilizer and cow urine were applied directly to the surface of the soil around the plant. Table 1 shows the chemical composition of organic fertilizers used in the experiment. In fertilization with liquid biofertilizers were applied $\left(\mathrm{kg} \mathrm{ha}^{-1}\right) 2.6 \mathrm{~N}, 7.0 \mathrm{P}_{2} \mathrm{O}_{5}, 7.3 \mathrm{~K}_{2} \mathrm{O}$, $4.3 \mathrm{Ca}, 3.8 \mathrm{Mg}, 0.5 \mathrm{~S}, 0.1 \mathrm{Zn}, 0.1 \mathrm{Cu}, 0.8 \mathrm{Fe}, 0.1 \mathrm{Mn}$, and $0.1 \mathrm{~B}$; and in fertilization with cow urine were applied (kg ha-1) $9.8 \mathrm{~N}, 0.3 \mathrm{P}_{2} \mathrm{O}_{5}, 2.3 \mathrm{~K}_{2} \mathrm{O}, 0.3 \mathrm{Ca}$, $0.4 \mathrm{Mg}, 1.1 \mathrm{~S}, 0.01 \mathrm{Zn}, 0.01 \mathrm{Cu}, 0.01 \mathrm{Fe}, 0.01 \mathrm{Mn}$, and $0.01 \mathrm{~B}$.

\section{Plant and soil chemical analysis}

Soil samples were collected from each plot in October 2011, at the end of the experiment, for analysis of chemical properties. Soil $\mathrm{pH}\left(\mathrm{H}_{2} \mathrm{O}\right)(1: 2.5)$ and electrical conductivity (EC) were determined using standard procedures (Embrapa, 1999). Extractable P was determined by the Mehlich-1 method (Embrapa, 1999). Sodium and $\mathrm{K}$ were determined by flame photometry, and $\mathrm{Ca}$ and $\mathrm{Mg}$ were determined by EDTA titration.

Leaf samples were weighed and dried in a laboratory oven at $65{ }^{\circ} \mathrm{C}$, and then ground to pass through a $1-\mathrm{mm}$ sieve for nutrient analyses. Macro- and micronutrients were measured in plant 
Table 1. Chemical composition of the organic fertilizers used in the experiment

\begin{tabular}{lcc}
\hline Attribute & Cow urine & Liquid biofertilizer \\
\hline $\mathrm{pH}$ & 8.4 & 6.8 \\
$\mathrm{EC}(\mathrm{dS} \mathrm{m}-1)$ & 21.30 & 8.99 \\
$\mathrm{C}\left(\mathrm{g} \mathrm{L}^{-1}\right)$ & 0.0 & 241.62 \\
$\mathrm{~N}\left(\mathrm{~g} \mathrm{~L}^{-1}\right)$ & 5.23 & 1.41 \\
$\mathrm{P}\left(\mathrm{g} \mathrm{L}^{-1}\right)$ & 0.06 & 1.62 \\
$\mathrm{~K}\left(\mathrm{~g} \mathrm{~L}^{-1}\right)$ & 1.00 & 3.20 \\
$\mathrm{Ca}\left(\mathrm{g} \mathrm{L}^{-1}\right)$ & 0.18 & 2.29 \\
$\mathrm{Mg}\left(\mathrm{g} \mathrm{L}^{-1}\right)$ & 0.12 & 2.00 \\
$\mathrm{Na}\left(\mathrm{g} \mathrm{L}^{-1}\right)$ & 0.21 & 0.43 \\
$\mathrm{~S}\left(\mathrm{~g} \mathrm{~L}^{-1}\right)$ & 0.26 & 0.55 \\
$\mathrm{Zn}\left(\mathrm{mg} \mathrm{L}^{-1}\right)$ & 1.0 & 9 \\
$\mathrm{Cu}\left(\mathrm{mg} \mathrm{L}^{-1}\right)$ & 1.0 & 33 \\
$\mathrm{Fe}\left(\mathrm{mg} \mathrm{L}^{-1}\right)$ & 5.0 & 437 \\
$\mathrm{Mn}\left(\mathrm{mg} \mathrm{L}^{-1}\right)$ & 1.0 & 37 \\
$\mathrm{~B}\left(\mathrm{mg} \mathrm{L}^{-1}\right)$ & 5.0 & 14 \\
\hline
\end{tabular}

material according to Embrapa (1999). Total N was determined by Kjeldhal digestion. Sodium and K were determined by flame photometry; $\mathrm{P}, \mathrm{B}$, and $\mathrm{Fe}$ by colorimetric determination; and $\mathrm{Ca}$ and $\mathrm{Mg}$ by atomic absorption spectrophotometry. Crude protein in sunflower seeds was calculated from the $\mathrm{N}$ content determined by the micro-Kjeldahl method, using 6.25 as the conversion factor (Zenebon et al., 2008).

\section{Growth parameters}

To analyze the growth of sunflower, 1.0 plant per plot was harvested every 15 days to determine the parameters of plant height stem diameter, shoot dry weight, and leaf area. From the results determined over the sunflower cycle, the relative growth rate (RGR) and leaf weight ratio (LWR) were calculated in accordance with Benincasa (2003). At the end of the experiment, corresponding to harvest at 110 days after sowing, stem diameter, plant height, shoot dry weight, leaf area, grain yield, capitulum diameter, and 1,000 seed weight were determined. Leaf area was determined according to Cairo et al. (2008), and shoot dry matter was determined according to Embrapa (1999). Relative mycorrhizal dependency (RMD) was determined according to Plenchette et al. (1983) using equation 1:

$$
\mathrm{RMD}=\frac{\mathrm{DWMP}-\mathrm{DWNMP}}{\mathrm{DWNMP}} \times 100
$$

where DWMP: dry weight of mycorrhizal plants; and DWNMP: dry weight of non-mycorrhizal plants.

\section{Statistical analysis}

For statistical analysis of the leaf tissue and soil attributes at the end of the experiment, analysis of variance ( $\mathrm{F}$ test) was performed in a randomized block design in a factorial arrangement, with three replicates. Mean values were compared by the Tukey test at $5 \%$ probability with 7.5 beta software Assistat (Silva, 1996). For statistical analysis of plant growth over time, analysis of variance was performed in a split-plot design, with treatments as the main plot and times as the subplot.

\section{RESULTS AND DISCUSSION}

\section{Nutrients in the soil and plant}

Exchangeable Ca levels (Table 2) were significantly higher $(p<0.05)$ in the LB $\left(2.76 \mathrm{cmol}_{\mathrm{c}} \mathrm{kg}^{-1}\right)$ and $\mathrm{MF}\left(2.93 \mathrm{cmol}_{\mathrm{c}} \mathrm{kg}^{-1}\right)$ treatments, compared to the other treatments studied, in the soil without inoculation with $G$. fasciculatum AMF. In soil with mycorrhization, the LB $\left(2.89 \mathrm{cmol}_{\mathrm{c}} \mathrm{kg}^{-1}\right)$ and $\mathrm{MF}\left(2.96 \mathrm{cmol}_{\mathrm{c}} \mathrm{kg}^{-1}\right)$ treatments also showed significantly higher Ca levels, compared to the other treatments. The same trend was found for $\mathrm{Mg}, \mathrm{K}$, and CEC levels in soils with and without inoculation with $\mathrm{AMF}$, where the $\mathrm{LB}$ and $\mathrm{MF}$ treatments were significantly higher. Exchangeable $\mathrm{Na}$ had significantly higher values in the LB and $\mathrm{CU}$ treatments, both in soils inoculated or not inoculated with AMF.

Fertilization with LB and MF led to significantly higher available $\mathrm{P}$ values in the soil (Table 2) compared to the other treatments studied, both in soils inoculated and not inoculated with AMF. Boron levels in the soil were significantly higher $(p<0.05)$ in treatments with LB and CU (Table 2), compared to the control treatment, both in soils inoculated and not inoculated with AMF, while fertilization with LB promoted higher Fe levels in the soil than the other treatments considered. Soil $\mathrm{pH}$ showed no significant difference among the treatments, while the soil EC was significantly higher in the LB and CU treatments $(p<0.05)$, compared to the MF and control treatments (Table 2).

Most of the changes in the soil chemical properties observed are explained by differences in nutrient inputs due to the application of LB, CU, and MF. Nutrient input brought about by the LB (Table 1) and MF treatments resulted in higher levels of $\mathrm{Ca}, \mathrm{Mg}, \mathrm{K}$ and $\mathrm{P}$ (Table 2) in soils that received these fertilizers, which resulted in a higher soil CEC for these treatments (Table 2). According to the reference values of Ribeiro et al. (1999), the exchangeable $\mathrm{Ca}$ and $\mathrm{Mg}$ levels in the soil (Table 2) in the $\mathrm{LB}$ and MF treatments are considered high, while $\mathrm{K}$ and $\mathrm{P}$ (Table 2 ) levels were considered high in all three treatments that received fertilization (IPA, 2008). In the control treatment, application of 
Table 2. Exchangeable cations, soil cation exchange capacity (CEC), P, B, Fe, pH in water, and soil electrical conductivity (EC) as a function of the treatments studied

\begin{tabular}{|c|c|c|c|c|c|c|c|c|}
\hline \multirow{2}{*}{ Mycorrhizal treatment } & \multicolumn{8}{|c|}{ Fertilization treatment } \\
\hline & LB & $\mathbf{C U}$ & MF & Control & LB & $\mathbf{C U}$ & MF & Control \\
\hline & \multicolumn{4}{|c|}{$\mathrm{Ca}^{2+}\left(\mathrm{cmol}_{\mathrm{c}} \mathrm{kg}^{-1}\right)$} & \multicolumn{4}{|c|}{$\mathrm{P}\left(\mathrm{mg} \mathrm{kg}^{-1}\right)$} \\
\hline With mycorrhiza & $2.97 \mathrm{Aa}$ & $1.50 \mathrm{Ba}$ & $3.14 \mathrm{Aa}$ & $1.22 \mathrm{Ba}$ & $50.13 \mathrm{Aa}$ & $30.23 \mathrm{Ba}$ & $65.54 \mathrm{Aa}$ & $20.60 \mathrm{Ba}$ \\
\hline \multirow[t]{2}{*}{ Without mycorrhiza } & $3.10 \mathrm{Aa}$ & $1.75 \mathrm{Ba}$ & $3.16 \mathrm{Aa}$ & $1.30 \mathrm{Ba}$ & $61.68 \mathrm{Aa}$ & $41.60 \mathrm{Ba}$ & $73.03 \mathrm{Aa}$ & $26.69 \mathrm{Ba}$ \\
\hline & \multicolumn{4}{|c|}{$\mathrm{Mg}^{2+}\left(\mathrm{cmol}_{\mathrm{c}} \mathrm{kg}^{-1}\right)$} & \multicolumn{4}{|c|}{ B $\left(\mathrm{mg} \mathrm{kg}^{-1}\right)$} \\
\hline With mycorrhiza & $1.50 \mathrm{Aa}$ & $0.93 \mathrm{Ba}$ & $1.53 \mathrm{Aa}$ & $0.74 \mathrm{Ba}$ & $0.81 \mathrm{ABa}$ & $1.20 \mathrm{Aa}$ & $0.46 \mathrm{BCa}$ & $0.13 \mathrm{Ca}$ \\
\hline \multirow{2}{*}{ Without mycorrhiza } & $1.57 \mathrm{Aa}$ & $0.96 \mathrm{Ba}$ & $1.69 \mathrm{Aa}$ & $0.77 \mathrm{Ba}$ & $0.72 \mathrm{ABa}$ & $1.10 \mathrm{Aa}$ & $0.41 \mathrm{BCa}$ & $0.15 \mathrm{Ca}$ \\
\hline & \multicolumn{4}{|c|}{$\mathrm{K}^{+}\left(\mathrm{cmol}_{\mathrm{c}} \mathrm{kg}^{-1}\right)$} & \multicolumn{4}{|c|}{$\mathrm{Fe}\left(\mathrm{mg} \mathrm{kg}{ }^{-1}\right)$} \\
\hline With mycorrhiza & $0.59 \mathrm{Aa}$ & $0.37 \mathrm{Ba}$ & $0.62 \mathrm{Aa}$ & $0.17 \mathrm{Ca}$ & $37.14 \mathrm{Aa}$ & $21.36 \mathrm{Ba}$ & $16.98 \mathrm{BCa}$ & $11.72 \mathrm{Ca}$ \\
\hline \multirow[t]{2}{*}{ Without mycorrhiza } & $0.65 \mathrm{Aa}$ & $0.41 \mathrm{Ba}$ & $0.71 \mathrm{Aa}$ & $0.19 \mathrm{Ca}$ & $35.39 \mathrm{Aa}$ & $20.49 \mathrm{Ba}$ & $17.86 \mathrm{BCa}$ & $13.47 \mathrm{Ca}$ \\
\hline & \multicolumn{4}{|c|}{$\mathrm{Na}^{+}\left(\mathrm{cmol}_{\mathrm{c}} \mathrm{kg}^{-1}\right)$} & \multicolumn{4}{|c|}{$\mathrm{pH}\left(\mathrm{H}_{2} \mathrm{O}\right)$} \\
\hline With mycorrhiza & $0.29 \mathrm{Aa}$ & $0.22 \mathrm{Aa}$ & $0.12 \mathrm{Ba}$ & $0.06 \mathrm{Ba}$ & $5.76 \mathrm{Aa}$ & $5.91 \mathrm{Aa}$ & $5.91 \mathrm{Aa}$ & $6.12 \mathrm{Aa}$ \\
\hline \multirow[t]{2}{*}{ Without mycorrhiza } & $0.26 \mathrm{Aa}$ & $0.24 \mathrm{Aa}$ & $0.10 \mathrm{Ba}$ & $0.05 \mathrm{Ba}$ & $5.91 \mathrm{Aa}$ & $5.97 \mathrm{Aa}$ & $5.73 \mathrm{Aa}$ & $6.16 \mathrm{Aa}$ \\
\hline & \multicolumn{4}{|c|}{$\mathrm{CEC}\left(\mathrm{cmol}_{\mathrm{c}} \mathrm{kg}^{-1}\right)$} & \multicolumn{4}{|c|}{$\mathrm{EC}\left(\mathrm{dS} \mathrm{m}^{-1}\right)$} \\
\hline With mycorrhiza & $7.07 \mathrm{Aa}$ & $4.73 \mathrm{Ba}$ & $7.37 \mathrm{Aa}$ & $4.07 \mathrm{Ca}$ & $0.49 \mathrm{Aa}$ & $0.55 \mathrm{Aa}$ & $0.31 \mathrm{Ba}$ & $0.07 \mathrm{Ca}$ \\
\hline Without mycorrhiza & $7.40 \mathrm{Aa}$ & $5.12 \mathrm{Ba}$ & $7.57 \mathrm{Aa}$ & $4.18 \mathrm{Ca}$ & $0.47 \mathrm{Aa}$ & $0.50 \mathrm{Aa}$ & $0.26 \mathrm{Ba}$ & $0.08 \mathrm{Ca}$ \\
\hline
\end{tabular}

LB: liquid biofertilizer, CU: cow urine, MF: mineral fertilizer, and unfertilized treatment - control. Values followed by the same letter are not significantly different at $\mathrm{p}<0.05$ (Tukey test). Upper case letters compare data within rows and lower case letters compare data within columns.

dolomite limestone possibly caused maintenance of moderate levels of $\mathrm{Ca}$ and $\mathrm{Mg}$ in the soil.

High levels of $\mathrm{B}$ and $\mathrm{Fe}$ in liquid biofertilizer and $B$ in cow urine (Table 1) resulted in higher values of these nutrients in the soils of the LB and CU treatments compared to the control (Table 2), both in treatments with and without inoculation of AMF. Soil EC is considered low; however, treatments with LB and CU increased EC by 600 and $680 \%$, respectively, compared to the control treatment due to the input of nutrients added by liquid biofertilizer and cow urine (Table 1) in soil without the inoculation of $G$. fasciculatum. The same trend was found in the soil inoculated with AMF.

In this study, there was no significant difference between levels of nutrients in soils with and without inoculation with $G$. fasciculatum AMF (Table 2). However, Wu et al. (2005) found that inoculation of soil with $\mathrm{AMF}$ resulted in an increase in soil $\mathrm{P}$ contents, emphasizing that these fungi may play a significant role in improving the bioavailability of $\mathrm{P}$ in the soil.

Nitrogen and $K$ levels in shoots were significantly affected by fertilization ( $p<0.05)$. Application of LB, $\mathrm{CU}$, and MF led to a significant increase in $\mathrm{N}$ and $\mathrm{K}$ in the shoot dry matter of sunflower in relation to the control treatment, both in plants associated with AMF or not (Table 3). P levels in the shoot dry matter were significantly higher in the LB and MF treatments compared to other treatments in plants without mycorrhization. In the plants associated with $G$. fasciculatum, however, P levels in shoots were higher in all fertilized treatments, compared to the control treatment. Calcium levels in the shoot dry matter were significantly higher in the $\mathrm{LB}$ and MF treatments $(\mathrm{p}<0.05)$ compared to the other treatments studied, while B was statistically higher in the LB and CU treatments, both in plants associated with AMF or not (Table 3). Fe levels in the shoot dry matter of sunflower were statistically higher in the LB treatment than all three other treatments considered.

Although inoculation with $G$. fasciculatum did not lead to a significant difference in nutrients in the soil (Table 2), the association of AMF with sunflower plants exerted a stimulating effect on $\mathrm{P}$ and $\mathrm{K}$ uptake by the plants (Table 3 ). In general, plants associated with AMF had higher levels of $\mathrm{N}$, $\mathrm{P}$, and $\mathrm{K}$ in the shoot dry matter compared to nonmycorrhizal plants (Table 3), but significant gains $(p<0.05)$ were only observed in $\mathrm{K}$ and $\mathrm{P}$ in the shoots in the CU (116 and $42 \%$, respectively) and control (122 and $95 \%$, respectively) treatments in plants with mycorrhization.

The higher levels of $\mathrm{N}$ and $\mathrm{K}$ in the shoot dry matter in the LB, CU, and MF treatments reflect the uptake of these nutrients due to the input of the fertilizers applied. The $\mathrm{N}$ and $\mathrm{K}$ levels in plant tissue are considered suitable for sunflower development (Ribeiro et al., 1999), both in plants associated with 
Table 3. Macro- and micronutrients in shoot dry matter of sunflower, capitulum diameter, 1,000 seed weight, crude protein in the seeds, and yield of sunflower as a function of the treatments studied

\begin{tabular}{|c|c|c|c|c|}
\hline \multirow{2}{*}{ Mycorrhizal treatment } & \multicolumn{4}{|c|}{ Fertilization treatment } \\
\hline & LB & CU & MF & Control \\
\hline & \multicolumn{4}{|c|}{$N\left(g_{k g}-1\right)$} \\
\hline With mycorrhiza & $37.89 \mathrm{Aa}$ & $40.09 \mathrm{Aa}$ & $34.35 \mathrm{Aa}$ & $11.43 \mathrm{Ba}$ \\
\hline \multirow[t]{2}{*}{ Without mycorrhiza } & $38.22 \mathrm{Aa}$ & $38.45 \mathrm{Aa}$ & $35.28 \mathrm{Aa}$ & $14.65 \mathrm{Ba}$ \\
\hline & \multicolumn{4}{|c|}{$\mathrm{P}\left(\mathrm{g} \mathrm{kg}^{-1}\right)$} \\
\hline With mycorrhiza & $5.27 \mathrm{Aa}$ & $2.25 \mathrm{Bb}$ & $4.47 \mathrm{Aa}$ & $1.38 \mathrm{Bb}$ \\
\hline \multirow[t]{2}{*}{ Without mycorrhiza } & $6.31 \mathrm{Aa}$ & $4.87 \mathrm{Aa}$ & $5.54 \mathrm{Aa}$ & $3.06 \mathrm{Ba}$ \\
\hline & \multicolumn{4}{|c|}{$\mathrm{K}\left(\mathrm{g} \mathrm{kg}^{-1}\right)$} \\
\hline With mycorrhiza & $24.43 \mathrm{Aa}$ & $21.82 \mathrm{Ab}$ & $25.60 \mathrm{Aa}$ & $10.19 \mathrm{Bb}$ \\
\hline \multirow[t]{2}{*}{ Without mycorrhiza } & $27.11 \mathrm{Aa}$ & $31.04 \mathrm{Aa}$ & $27.56 \mathrm{Aa}$ & $19.85 \mathrm{Ba}$ \\
\hline & \multicolumn{4}{|c|}{$\mathrm{Ca}\left(\mathrm{g} \mathrm{kg}^{-1}\right)$} \\
\hline With mycorrhiza & $21.13 \mathrm{Aa}$ & $13.93 \mathrm{Ba}$ & $21.96 \mathrm{Aa}$ & $12.91 \mathrm{Ba}$ \\
\hline \multirow[t]{2}{*}{ Without mycorrhiza } & $21.96 \mathrm{Aa}$ & $12.27 \mathrm{Ba}$ & $20.58 \mathrm{Aa}$ & $11.16 \mathrm{Ba}$ \\
\hline & \multicolumn{4}{|c|}{$\mathrm{Fe}\left(\mathrm{mg} \mathrm{kg}^{-1}\right)$} \\
\hline With mycorrhiza & $296.01 \mathrm{Aa}$ & $135.53 \mathrm{Bb}$ & $143.51 \mathrm{Bb}$ & $108.55 \mathrm{Bb}$ \\
\hline \multirow[t]{2}{*}{ Without mycorrhiza } & $345.83 \mathrm{Aa}$ & $257.74 \mathrm{Ba}$ & $263.80 \mathrm{Ba}$ & $225.81 \mathrm{Ba}$ \\
\hline & \multicolumn{4}{|c|}{$\mathrm{B}\left(\mathrm{mg} \mathrm{kg}^{-1}\right)$} \\
\hline With mycorrhiza & $60.78 \mathrm{Aa}$ & $63.82 \mathrm{Aa}$ & $42.50 \mathrm{Ba}$ & $38.70 \mathrm{Ba}$ \\
\hline \multirow[t]{2}{*}{ Without mycorrhiza } & $65.35 \mathrm{Aa}$ & $66.87 \mathrm{Aa}$ & $43.27 \mathrm{Ba}$ & $40.98 \mathrm{Ba}$ \\
\hline & \multicolumn{4}{|c|}{ Capitulum diameter $(\mathrm{cm})$} \\
\hline With mycorrhiza & $16.53 \mathrm{ABb}$ & $15.77 \mathrm{Bb}$ & $17.50 \mathrm{Ab}$ & $13.07 \mathrm{Cb}$ \\
\hline \multirow[t]{2}{*}{ Without mycorrhiza } & $18.30 \mathrm{ABa}$ & $17.20 \mathrm{Ba}$ & $19.07 \mathrm{Aa}$ & $15.07 \mathrm{Ca}$ \\
\hline & \multicolumn{4}{|c|}{ 1,000 seed weight $(\mathrm{g})$} \\
\hline With mycorrhiza & $62.8 \mathrm{Aa}$ & $52.73 \mathrm{ABb}$ & $66.50 \mathrm{Ab}$ & $40.17 \mathrm{Bb}$ \\
\hline \multirow[t]{2}{*}{ Without mycorrhiza } & $70.60 \mathrm{Aa}$ & $65.33 \mathrm{ABa}$ & $78.33 \mathrm{Aa}$ & $55.00 \mathrm{Ba}$ \\
\hline & \multicolumn{4}{|c|}{ Crude protein in the seeds (\%) } \\
\hline With mycorrhiza & $22.72 \mathrm{Aa}$ & $23.25 \mathrm{Aa}$ & $23.16 \mathrm{Aa}$ & $20.13 \mathrm{Ba}$ \\
\hline \multirow[t]{2}{*}{ Without mycorrhiza } & $22.13 \mathrm{Aa}$ & $24.18 \mathrm{Aa}$ & $23.39 \mathrm{Aa}$ & $20.56 \mathrm{Ba}$ \\
\hline & \multicolumn{4}{|c|}{ Grain yield (kg ha-1) } \\
\hline With mycorrhiza & $1145.8 \mathrm{ABb}$ & $1020.8 \mathrm{Bb}$ & $1268.0 \mathrm{Ab}$ & $395.8 \mathrm{Cb}$ \\
\hline Without mycorrhiza & $1388.9 \mathrm{ABa}$ & $1223.6 \mathrm{Ba}$ & $1459.7 \mathrm{Aa}$ & $606.9 \mathrm{Ca}$ \\
\hline
\end{tabular}

LB: liquid biofertilizer, CU: cow urine, MF: mineral fertilizer, and unfertilized treatment - control. Values followed by the same letter are not significantly different at $\mathrm{p}<0.05$ (Tukey test). Upper case letters compare data within rows and lower case letters compare data within columns.

AMF or not. Fertilization with liquid biofertilizer and chemical fertilizer resulted in higher Ca uptake by plants, resulting in significantly higher levels in the shoots in the LB and MF treatments. This behavior occurred both in treatments with and without the inoculation of $G$. fasciculatum.

The higher levels of B in soils fertilized with LB and CU (Table 1) allowed greater uptake of this element by sunflower, resulting in adequate levels of $\mathrm{B}$ in plant tissue in these treatments (Ribeiro et al., 1999), both in plants associated with AMF or not. The lower levels of $\mathrm{P}$ and $\mathrm{K}$ in soils in the $\mathrm{CU}$ and control treatments may have contributed to greater uptake of these nutrients in the plants associated with $G$. fasciculatum AMF in these treatments, compared to plants without mycorrhization (Table 3), resulting in significantly higher levels of $\mathrm{P}$ and $\mathrm{K}$ in shoot dry matter. High available $\mathrm{P}$ content in the soil can reduce the efficiency of mycorrhizal symbiosis for $\mathrm{P}$ uptake by plants (Wong et al., 2007). The P levels in sunflower shoots in all the treatments associated with AMF are considered appropriate (Ribeiro et al., 
1999). In plants without mycorrhization, the $\mathrm{P}$ levels were only suitable in the LB and MF treatments.

The association of sunflower with $G$. fasciculatum AMF led to greater uptake of Fe by the plants, resulting in significantly higher levels in the shoot dry matter, compared to plants without mycorrhization. Roots colonized by mycorrhizal fungi allow utilization of a larger soil volume due to the extent of fungal hyphae in several centimeters into the soil, allowing greater uptake of nutrients (Wu et al., 2005). Fe levels in plant tissue are considered suitable for the growth of sunflower (Ribeiro et al., 1999) in all treatments inoculated with AMF. In plants without mycorrhization, $\mathrm{Fe}$ levels in the shoots were only suitable in the LB treatment, possibly due to the high concentration of Fe in liquid biofertilizer (Table 1).

\section{Growth parameters}

Figure $1 \mathrm{a}$ and $1 \mathrm{~b}$ shows the data of plant height and stem diameter at different times during the sunflower plant cycle. Plant height increased throughout the sunflower cycle, and at 110 days after sowing reached the values of 102.6, 98.2, 104.9, and $80.3 \mathrm{~cm}$ in the LB, CU, MF, and control treatments, respectively, in plants without mycorrhization, and values of $116.6,113.0,119.5$, and $95.6 \mathrm{~cm}$ in the $\mathrm{LB}$, $\mathrm{CU}, \mathrm{MF}$, and control treatments, respectively, in plants associated with AMF. The sunflower plants subjected to the LB, CU, and MF treatments showed significantly higher values $(\mathrm{p}<0.05)$ for plant height (a)

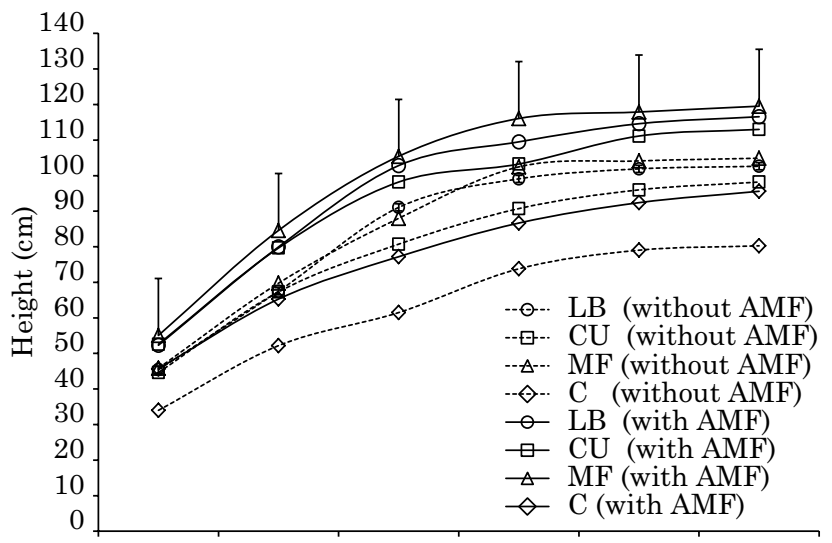

(c)

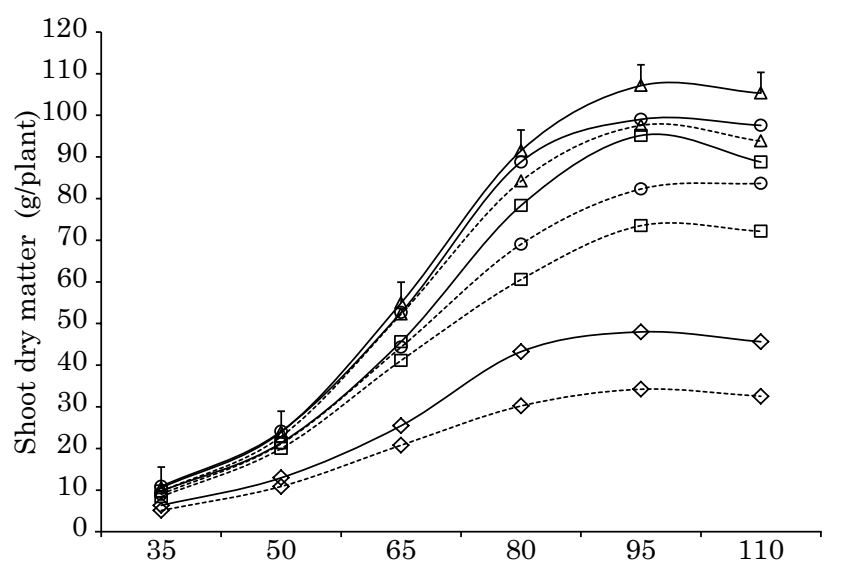

(b)

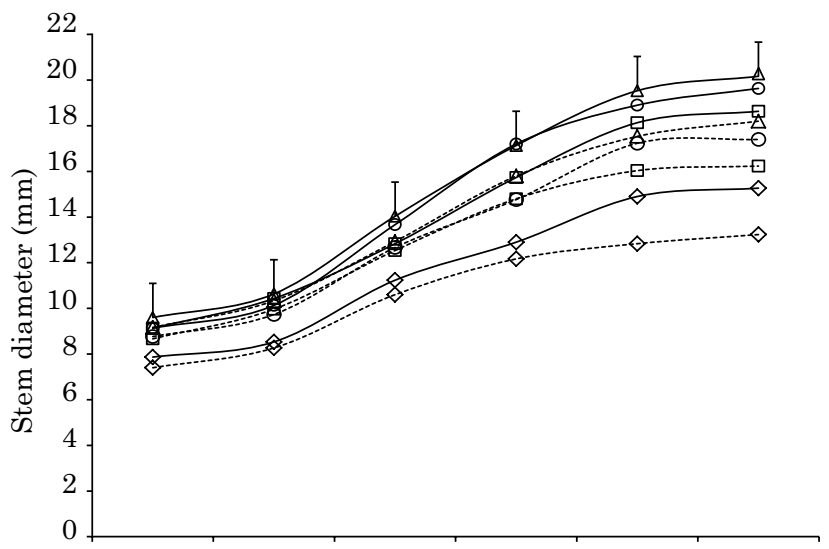

(d)

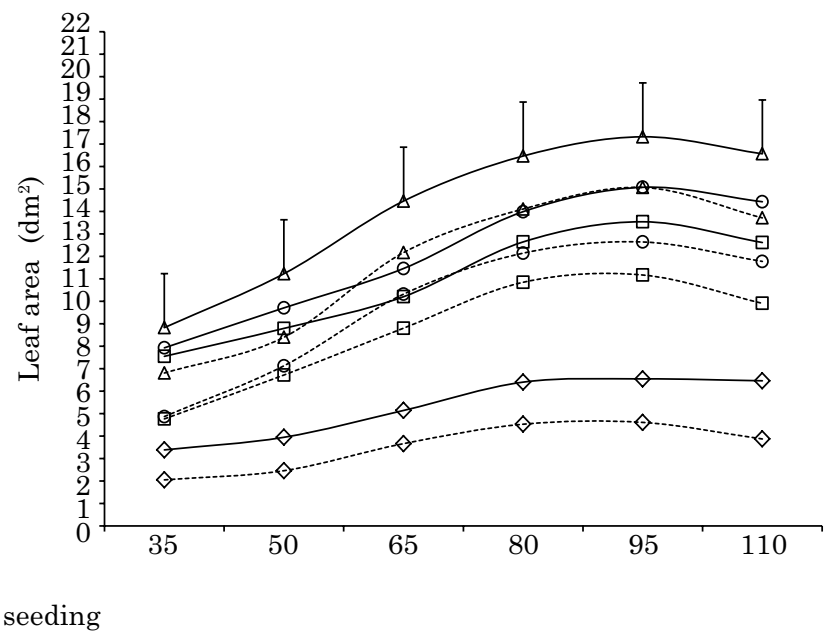

Figure 1. Plant height (a), stem diameter (b), shoot dry weight (c) and leaf area (d) of sunflower as a function of the application of fertilizers and time under cultivation. Vertical bars indicate LSD $_{0.05}$ for fertilization treatments within each time under cultivation. LB: liquid biofertilizer, CU: cow urine, MF: mineral fertilizer, and C: unfertilized treatment - control. 
than the control treatment. This behavior occurred both in treatments with and without mycorrhization, especially as of 65 days after sowing.

Figure $1 \mathrm{~b}$ shows that there was gradual growth in stem diameter of sunflower with maturity of the crop. The maximum stem diameter values occurred at 110 days after sowing, and ranged from $13.2 \mathrm{~mm}$ (C) to $18.2 \mathrm{~mm}(\mathrm{MF})$ in non-mycorrhizal plants, and from $15.3 \mathrm{~mm}$ (C) to $20.2 \mathrm{~mm}$ (MF) in mycorrhizal plants.

As of 50 days after sowing, the plants associated with AMF had significantly higher values for plant height than plants without mycorrhization, in all the treatments studied (Figure 1a). This increase was also observed for the values of stem diameter; however, significant differences only occurred 95 days after sowing (Figure 1b). These results may reflect higher $\mathrm{P}, \mathrm{K}$, and $\mathrm{Fe}$ uptake by plants in association with mycorrhizal fungi (Table 3).

Shoot dry matter (SDM) and leaf area (LA) are shown in figure 1. Growth analysis of sunflower showed an increase in SDM throughout the plant cycle until 95 days after sowing, decreasing at 110 days after sowing (Figure 1c). The maximum SDM values ranged from 34.2 (control) to $97.6 \mathrm{~g} / \mathrm{plant}$ (MF) in plants not inoculated with $G$. fasciculatum, and from 48.0 (control) to $107.1 \mathrm{~g} /$ plant (MF) in plants with mycorrhization. In plants inoculated with AMF, Figure 1c shows that from 65 days after sowing, plants fertilized with the LB, CU, and MF treatments had significantly higher SDM values than plants in the control treatment $(p<0.05)$, and the treatment with MF showed significantly higher SDM values than all the other treatments. In plants without mycorrhization, though as of 80 days after sowing, the treatment with MF showed significantly higher SDM values than all the other treatments; and plants fertilized with $\mathrm{BL}$ and $\mathrm{CU}$ showed significantly higher SDM values than the control treatment.

The increase in plant height and SDM along with time under cultivation confirms the findings of Castro and Farias (2005), which emphasize that dry matter accumulation is directly related to phenotype and environment. The control plants showed limited growth, probably due to nutrient deficiency in the unfertilized soil. The higher values of plant height and SDM in the LB, CU, and MF treatments compared to the control (not fertilized) may reflect the nutrient input provided by fertilization in sunflower cultivation. The loss in SDM at 110 days after planting may be related to an increase in respiratory activity and loss of sunflower leaves, which is not covered by proportional dry matter accumulation in shoots. This behavior reflects the reduced growth rate in the maturation period of the sunflower plant (Benincasa, 2003).

There was a gradual increase in LA with increased time under cultivation, with maximum values at 95 days after sowing, in all treatments (Figure 1d). Higher values of LA were observed in the MF, LB, and CU treatments $(17.32,15.07$, and $13.54 \mathrm{dm}^{2} /$ plant, respectively), which were significantly higher than in the control treatment $\left(6.55 \mathrm{dm}^{2} /\right.$ plant$)$. In general, the LA of the MF treatment was significantly higher than all three other treatments considered in the plants inoculated with AMF. This behavior also occurred in plants not associated with AMF, with higher values of LA observed in plants under MF, LB, and CU treatments (15.07, 12.64, and $11.17 \mathrm{dm}^{2} /$ plant, respectively). The LA of the control treatment was significantly lower than all treatments with fertilization. As of 95 days after sowing, the sunflower plants showed a slight decrease in LA until the end of the growing season. This occurred both in plants with and without inoculation with AMF. The higher values of LA and stem diameter in plants fertilized with $\mathrm{LB}, \mathrm{CU}$, and $\mathrm{MF}$ in relation to the control treatment, both in treatments with and without mycorrhization, reflect the provision of nutrients from fertilizers used in sunflower cultivation. The decrease in leaf area observed in all treatments during the final stage of development reflects senescence and leaf drop.

Figure 1c shows that as of 80 days after sowing, plants associated with AMF had significantly higher SDM values $(\mathrm{p}<0.05)$ compared to non-mycorrhizal plants, in all the treatments studied. However, the values of $\mathrm{LA}$ in the $\mathrm{LB}$ and $\mathrm{CU}$ treatments were significantly higher in plants associated with AMF compared to plants without mycorrhization only 95 days after seeding (Figure $1 \mathrm{~d}$ ). The significantly higher values of $\mathrm{P}, \mathrm{K}$, and $\mathrm{Fe}$ in the leaves of plants associated with AMF (Table 3) may have contributed to the higher values of SDM and LA in these plants.

The relative growth rate (RGR) showed maximum values at 50 to 65 days after sowing and decreased with maturation of the plants in all treatments (Figure 2a). At 110 days after sowing, the RGRs were negative in all treatments, except in the LB treatment in plants not inoculated. The RGR was significantly higher in plants subjected to the LB, $\mathrm{CU}$, and MF treatments compared to the control treatment at 65 to 80 days after sowing in plants without mycorrhization (Figure 2a). The decrease in RGR with maturation of the plants in all treatments corroborate the results of Braz and Rossetto (2009), who also found a reduction in the relative growth rate of sunflower over the crop cycle, reaching negative values at 100 days after sowing. Negative values of the RGR at the end of the sunflower cycle occurred because of reduction in SDM in the final period (110 days), which may be related to excessive death of leaves in relation to grain yield. Barni et al. (1995), also working with sunflower, found that the RGR was high at the beginning of the cycle and reduced to zero at physiological maturity, due to gradual growth of tissues such as flowers and fruits. Benicasa (2003) emphasized that the relative 
(a)

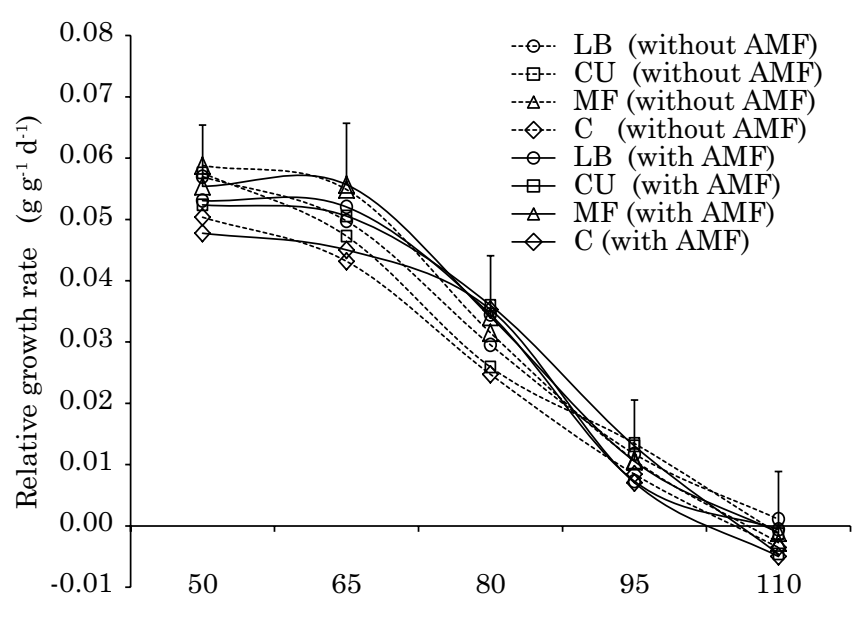

(b)

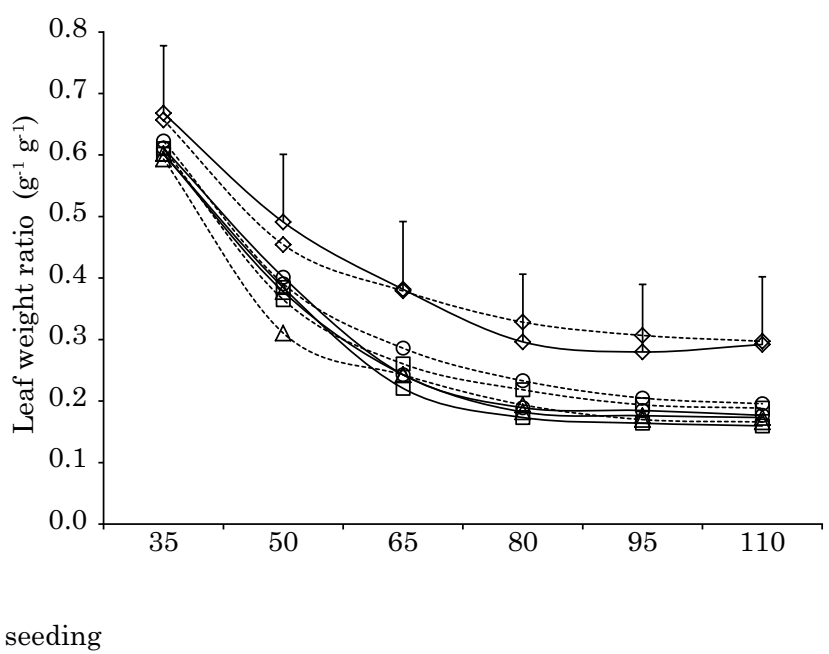

Figure 2. Relative growth rate (a) and leaf weight ratio (b) of sunflower as a function of fertilization treatments. Vertical bars indicate $\mathrm{LSD}_{0.05}$ for fertilization treatments within each time under cultivation. LB: liquid biofertilizer, CU: cow urine, MF: mineral fertilizer, and C: unfertilized treatment - control.

growth rate represents the growth of plant weight, height, or leaf area over a given period compared to the previous period, and tends to decrease over the crop cycle.

The leaf weight ratio (LWR) values also decreased with the maturation of sunflower in all the treatments studied (Figure $2 b$ ). The maximum LWR values occurred in the early development of sunflower, at 35 days after seeding in the control treatment, in plants associated with AMF or not (0.292 and $0.294 \mathrm{~g} \mathrm{~g}^{-1}$, respectively). However, in plants with AMF, LWR values were significantly higher in the control treatment compared to the LB, CU, and MF treatments only as of 65 days after seeding. In plants without mycorrhization, the control treatment showed significantly higher SDM values than MF only as of 80 days after sowing. The LWR describes physiological behavior, expressing what part of the dry matter fraction is not exported from the leaves to the rest of the plant (Cairo et al., 2008). The lower values of LWR of plants fertilized with $L B, C U$, and MF compared to the control indicate that sunflower plants under fertilization showed more efficient export of the material produced in the leaves to other organs of the plant, which is a favorable phenomenon for filling the achenes and, consequently, increasing grain yield.

\section{Yield parameters and relative mycorrhizal dependency (RMD)}

Table 3 shows that the capitulum diameter value in the MF treatment $(17.50 \mathrm{~cm})$ was statistically higher than the CU $(15.77 \mathrm{~cm})$ and control $(13.07 \mathrm{~cm})$ treatments, but there was no significant difference compared to the LB treatment $(16.53 \mathrm{~cm})$ in plants not associated with AMF. This increase in the capitulum diameter value was also observed in plants associated with $\mathrm{AMF}$, with values significantly higher in the MF, LB, and CU treatments than the control treatment.

Only the BL and MF treatments showed 1,000 seed weight values statistically higher than the control treatment, considering both plants without and with mycorrhization (Table 3). The grain yield of sunflower in the $\mathrm{LB}\left(1,145.8 \mathrm{~kg} \mathrm{ha}^{-1}\right)$, CU (1,020.8 $\left.\mathrm{kg} \mathrm{ha}^{-1}\right)$, and MF $\left(1,268.0 \mathrm{~kg} \mathrm{ha}^{-1}\right)$ treatments were significantly higher compared to the control treatment $\left(395.8 \mathrm{~kg} \mathrm{ha}^{-1}\right)$ in plants without mycorrhization. The same occurred in plants associated with $\mathrm{AMF}$, with grain yield values significantly higher in the LB, CU, and MF treatments $(1388.9,1223.6$, and $1,459.7 \mathrm{~kg}^{\mathrm{ha}}-1$, respectively) compared to the control treatment $(606.9 \mathrm{~kg} \mathrm{ha}-1)$. Although the $\mathrm{LB}$ and $\mathrm{CU}$ treatments have lower levels of $\mathrm{N}, \mathrm{P}$, and $\mathrm{K}$ compared to the MF treatment, it may be that other elements such as $\mathrm{Ca}, \mathrm{Mg}$, and $\mathrm{S}$, and micronutrients present in those fertilizers were reflected in the yield parameters of sunflower.

The yield parameters were significantly affected by mycorrhization $(p<0.05)$. In general, the sunflower plants in association with AMF showed significantly higher values of the capitulum diameter, 1,000 seed weight, and grain yield parameters compared to the treatment without inoculation with AMF (Table 3). These results reflect the better development of plants associated with $\mathrm{AMF}$, due to greater uptake of nutrients $\mathrm{P}, \mathrm{K}$ and $\mathrm{Fe}$ in these plants. 
The higher values of capitulum diameter, 1,000 seed weight, and grain yield in fertilized treatments reflects the higher nutrient levels in the soils of these treatments compared to the control treatment. Studies showing the association of sunflower plants with AMF are rare in the literature. In this study, the higher values of capitulum diameter and grain yield showed a beneficial symbiosis between mycorrhizal fungi and sunflower. Ambrosano et al. (2010) also found a positive response in dry matter and grain yield due to inoculation with AMF in the sunflower crop.

Table 3 shows that crude protein values in sunflower seeds were significantly affected by fertilization $(p<0.05)$. Application of LB, CU, and MF led to significant increases of $12.87,15.5$ and $15.1 \%$ in crude protein in seeds, respectively, compared to the control treatment, in plants without mycorrhization. In plants associated with $\mathrm{AMF}$, the $\mathrm{LB}, \mathrm{CU}$, and MF treatments showed significant increases of 7.6, 17.6 , and $13.8 \%$, respectively, in relation to the control treatment (Table 3). There was no significant difference among the fertilized treatments. Crude protein levels in seeds were not significantly affected by inoculation with AMF in sunflower plants. Saad et al. (2007) found crude protein values in sunflower seeds $(24.8 \%)$ similar to the values found in this study. The high levels of $\mathrm{N}$ in cow urine and liquid biofertilizer (Table 1) and mineral fertilizer (urea) may have led to the higher values of crude protein in sunflower seeds in the LB, CU, and MF treatments, compared to the control, both in treatments with and without mycorrhization. Increases in crude protein in Lupin seeds as a function of $\mathrm{N}$ fertilization were also observed by Ciesiolka et al. (2007). These authors emphasize that $\mathrm{N}$ is an essential element for the formation of proteins and other important nitrogen compounds in the plant.

Figure 3 shows the values of relative mycorrhizal dependency (RMD) of the sunflower plants as a function of the treatment studied. The sunflower plants subjected to the control treatment showed significantly higher mycorrhizal dependence (35.2 \%) compared to the LB and MF treatments, which practically did not respond to inoculation when associated with AMF, with an RMD of 16.6 and $12.3 \%$ respectively. Treatment with cow urine (CU) showed intermediate mycorrhizal dependency $(23.1 \%)$ and showed no significant difference in regard to all other treatments. Lower RMD values of sunflower plants subjected to fertilization with LB and MF may reflect greater $\mathrm{P}$ input in the soil in these treatments, confirming the negative effect of increased phosphorus availability on plant-mycorrhizal symbiosis, as emphasized in the literature (Pellegrino et al., 2011).

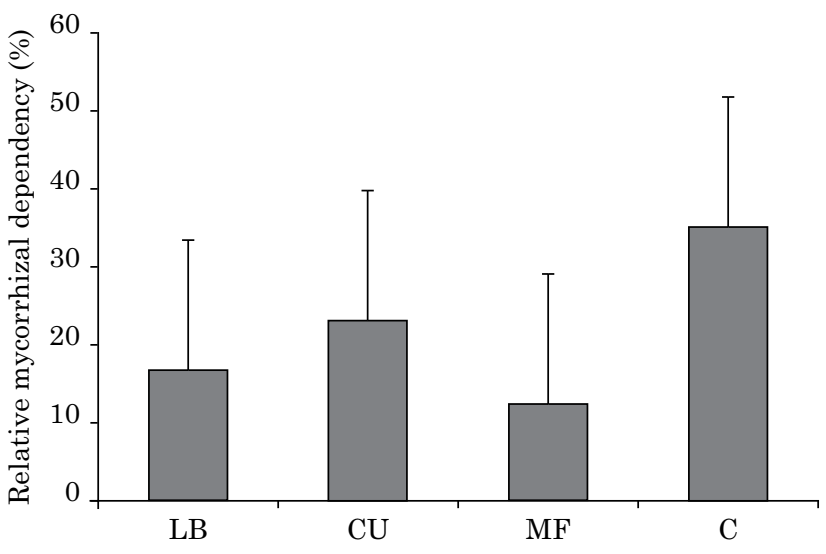

Figure 3. Relative mycorrhizal dependency (RMD) as a function of the fertilization treatments. Vertical bars indicate $\mathrm{LSD}_{0.05}$ for fertilization treatments. LB: liquid biofertilizer, CU: cow urine, MF: mineral fertilizer, and C: unfertilized treatment - control.

\section{CONCLUSIONS}

Liquid biofertilizer led to CEC and $\mathrm{P}$ values significantly similar to treatment with mineral fertilizer.

The application of liquid biofertilizer and mineral fertilizer led to higher values of capitulum diameter, 1,000 seed weight, and grain yield compared to the control treatment. Application of organic and mineral fertilizers on sunflower led to an increase in the plant height, shoot dry matter, and leaf area growth parameters both in treatments inoculated and not inoculated with mycorrhizal fungi.

The physiological parameters of relative growth rate, specific leaf area, leaf area ratio, and leaf weight ratio were positively influenced by fertilization, probably brought about by nutrient input from the fertilizers applied.

The sunflower plants associated with Glomus fasciculatum AMF had higher values of growth parameters in all the fertilization treatments evaluated compared to non-mycorrhizal plants.

\section{ACKNOWLEDGMENTS}

The authors are grateful to the PROEX (Pró-Reitoria de Extensão Universitária da UFRN) and the CNPq (Conselho Nacional de Desenvolvimento Científico e Tecnológico) for financial support. 


\section{REFERENCES}

Ambrosano EJ, Azcón R, Cantarella H, Ambrosano GMB, Schammass EA, Muraoka T, Trivelin, PCO, Rossi F, Guirado $\mathrm{N}$, Ungaro MRG, Teramoto JRS. Crop rotation biomass and arbuscular mycorrhizal fungi effects on sugarcane yield. Sci Agric. 2010;67:692-701.

Barni NA, Berlato MA, Santos AO, Sartori G. Análise de crescimento do girassol em resposta a cultivares, níveis de adubação e épocas de semeadura. Pesq Agropec Gaúcha. 1995;1:167-84.

Beltrão NPM. Agronegócio das oleaginosas no Brasil. Inf Agropec. 2005;26:14-7.

Benincasa MMP. Análise de crescimento de plantas: Noções básicas. Jaboticabal: Fundação de Apoio à Pesquisa, Ensino e Extensão; 2003.

Braghirolli FL, Sgrott AF, Pescador R, Uhlmann A, Stürmer SL. Fungos micorrízicos arbusculares na recuperação de florestas ciliares e fixação de carbono no solo. R Bras Ci Solo. 2012;36:733-43.

Braz MRS, Rossetto CAV. Crescimento de plantas de girassol em função do vigor de aquênios e da densidade de semeadura. Ci Rural. 2009;39:1989-96.

Cairo PAR, Oliveira LEM, Mesquita AC. Análise de crescimento de plantas. Vitória da Conquista: Universidade Estadual do Sudoeste da Bahia; 2008.

Cardoso EJBN, Tsai SM, Neves MCP, editores. Microbiologia do solo. Campinas: Sociedade Brasileira de Ciência do Solo; 1992.

Castro C, Farias JRB. Ecofisiologia do girassol. In: Leite RMVLC, Brighenti AM, Castro C, editores. Girassol no Brasil. Londrina: Empresa Brasileira de Pesquisa Agropecuária; 2005. p.163-218.

Ciesiolka D, Muzquiz M, Burbano C, Pedrosa MM, Wysocki W, Gulewicz K. Relationship between nitrogen form and the development and yield of Lupinus albus L. from different countries. Span J Agric Res. 2007;5:226-31.

Empresa Brasileira de Pesquisa Agropecuária - Embrapa. Manual de análises químicas de solos, plantas e fertilizantes. Brasília; 1999.

Empresa Brasileira de Pesquisa Agropecuária - Embrapa. Sistema brasileiro de classificação de solos. 2a ed. Rio de Janeiro; 2006.

Figueiredo MVB, Burity HA, Stamford NP, Santos CERS. Microrganismos e agrobiodiversidade: $\mathrm{O}$ novo desafio para a agricultura. Guaíba: Agrolivros; 2008.
Instituto Pernambucano de Agropecuária - IPA. Recomendação de adubação para o Estado de Pernambuco. 2a ed. Recife; 2008.

Miragaya JCG. Biodiesel: Tendências no mundo e no Brasil. Inf Agropec. 2005;26:7-13.

Modesto PT, Scabora MH, Colodro G, Maltoni KL, Cassiolato AMR. Alterações em algumas propriedades de um Latossolo degradado com uso de lodo de esgoto e resíduos orgânicos. R Bras Ci Solo. 2009;33:1489-98.

Moura Filho ER, Alencar RD. Introdução à agroecologia. Ipanguaçu; Editora Instituto Federal do Rio Grande do Norte; 2008.

Pellegrino E, Bedini S, Avio L, Bonari E, Giovannetti M. Field inoculation effectiveness of native and exotic arbuscular mycorrhizal fungi in a Mediterranean agricultural soil. Soil Biol Biochem. 2011;4:367-76.

Penteado SR. Introdução à agricultura orgânica. Viçosa, MG: Aprenda Fácil; 2003.

Plenchette C, Fortin JA, Furlan V. Growth of several plant species to mycorrhizae in a soil of moderate P-fertility. Plant Soil. 1983;70:199-209.

Ribeiro AC, Guimarães PTG, Alvarez VVH, organizadores. Recomendações para o uso de corretivos e fertilizantes em Minas Gerais - $5^{\mathrm{a}}$ aproximação. Viçosa, MG: Comissão de Fertilidade do Solo do Estado de Minas Gerais; 1999.

Saad CEP, Ferreira WM, Borges FMO, Lara LB. Avaliação do gasto e consumo voluntário de rações balanceadas e semente de girassol para papagaios-verdadeiros (Amazona aestiva). $\mathrm{Ci}$ Agrotecnol. 2007;31:1176-83.

Silva AF, Pinto JM, França CRRS, Fernandes SC, Gomes TCA, Silva MSL, Matos ANB. Preparo e uso de biofertilizantes líquidos. Petrolina: Empresa Brasileira de Pesquisa Agropecuária; 2007.

Silva FAS. The Assistat Software: Statistical assistance. In: Anais do 6. International Conference on Computers in Agriculture; 1996; Cancun. Cancun: American Society of Agricultural Engineers, 1996. p.294-298.

Wong CC, Wu SC, Kuek C, Khan AG, Wong MH. The role of mycorrhizae associated with vetiver grown in $\mathrm{Pb}$-/Zn-contaminated soils: Greenhouse study. Restor Ecol. 2007;15:60-7.

Wu SC, Cao ZH, Li ZG, Cheung KC, Wong MH. Effects of biofertilizer containing $\mathrm{N}$-fixer, $\mathrm{P}$ and $\mathrm{K}$ solubilizers and AM fungi on maize growth: A greenhouse trial. Geoderma. 2005;125:155-66.

Zenebon O, Pascuet NS, Tiglea P. Métodos físico-químicos para análise de alimentos. São Paulo: Instituto Adolfo Lutz; 2008. 